ROCZNIKI TEOLOGICZNE

Tom LXVII, zeszyt $11-2020$

DOI: https://doi.org/10.18290/rt206711-3

REV. ROMAN BUCHTA

\title{
MYSTAGOGIC DIMENSION OF CHRISTIAN FORMATION IN THE FAMILY COMMUNITY
}

\begin{abstract}
A b s tra ct. The 2020 global coronavirus pandemic led to severe restrictions imposed on all areas of social life. These restrictions also limited the ability of the faithful to participate in daily liturgy and everyday Church life. Consequently, many faithful participated in the liturgical celebrations of Easter and consecutive paschal Sundays within their family communities. Pursuant to bishops' guidelines, direct preparation for the First Communion and the sacrament of penance and reconciliation took place within the family community. Families faced the challenge of taking on tasks that are normally reserved for the catechumenate. We can then pose the question of whether contemporary Christian families view themselves as a community of the "domestic Church." Are they aware of their mission and prepared to fulfil it? The purpose of this article is to highlight the mystagogic dimension of Christian formation in the family community. The author offers a reflection on the family as the focus of realisation of the mystery of the Church. He analyses the goals and tasks of the family catechumenate, as exercised due to participation of the family in the life and mission of the Church.
\end{abstract}

Keywords: mystagogy; Christian formation; family; community; domestic Church.

Due to the worldwide coronavirus pandemic, the year 2020 will remain an extraordinary turning point for humankind. A common sensation of fear in the face of the possibility of death, unknown so far to the contemporary generation, made many people think about the actual meaning of life, and rethink their values and priorities. Our world, constructed so laboriously, in which we felt secure and unrestricted, had been reduced in a flash to the basic space of our houses. In order to control the spread of the pandemic in Europe and around the world, authorities introduced detailed rules regulating almost every aspect of social, cultural and economic life. It is obvious that these limitations also

Rev. Roman Buchta DSc, PhD, Hab, Associate Professor at the University of Silesia, Faculty of Theology of the University of Silesia; address for correspondence: ul. Jordana 18, 40-043 Katowice, Poland; e-mail: roman.buchta@us.edu.pl; ORCID: https://orcid.org/0000-0001-9984-3910. 
affected the standards of religious life. A moving expression of the gravity of this crisis was a service of the stations of the cross celebrated by Pope Francis in an empty St. Peter's Square. Church closings with the alternative to participate in Masses only via social media contributed to the fact that many people celebrated Easter liturgy and consecutive paschal Sundays in a community of only the closest members of their families.

In view of the pastoral context, pastors of the Church on numerous occasions referred to teachings within the family as the "domestic Church." Following the guidelines of diocesan bishops, quite commonly preparation for the sacrament of penance and reconciliation and for the First Communion was done within families. ${ }^{1}$ Families faced the challenge of performing tasks that are usually only achieved by the catechumenate. We can then ask: Do contemporary Christian families view themselves as a community of the "domestic Church"? Are they aware of their mission and are they prepared to fulfil it?

The purpose of this article is not to provide readers with specific analyses of these events, but rather to highlight the mystagogic dimension of Christian formation within the family community. It is thus necessary to present a theological and pastoral reflection of the family as the focus of realisation of the mystery of the Church. Such understanding of the family implies the necessity of families to assume the initiation function in family catechesis, as a vital part of participation in the mission of the Church. This reflection will be further examined in the second part of the article.

\section{THE FAMILY AS THE "DOMESTIC CHURCH"}

The origin of the notion the "domestic Church" goes back to the scriptures of the New Testament. It is especially visible in St. Paul's letters in which the apostle declares, on several occasions, that the Church realises herself in families. ${ }^{2}$ In the Church of apostolic times, the family home was a place of common

\footnotetext{
${ }^{1}$ Cf. Zarządzenie Arcybiskupa Katowickiego Wiktora Skworca z dnia 4 maja 2020 roku o częściowej zmianie regulacji prawnych, https://www.archidiecezjakatowicka.pl/o-diecezji/aktualnosci/1277czesciowa-zmiana-regulacji-prawnych-2 (May 14, 2020).

2 The notion the "domestic Church" does not convey all aspects of the Church depicted in New Testament. In Saint Paul's letters the Church denotes also other Christians living in a specific place and gathered around an altar to celebrate the Eucharist (see, e.g., 1 Cor 1:2; 10:16-18; 2 Cor 1:1; 1 Thess 1:1). In the Acts, Saint Luke refers to the Church as the community of all local communities (see Acts 11:26-30; 13:1-3); see also Elżbieta and Marek MARCZEWSCY, "'Kościół domowy.'
} 
prayer, singing psalms, and most of all celebrating Eucharist (Acts 2:46). The family, as a place of sharing faith and morality, played a vital religious role. The supernatural character of Christian matrimony, shown by St. Paul as the relationship between Jesus Christ's love and His Church (Eph 5:23-32), contributed to the perception of the family as an important centre of religious education. ${ }^{3}$

Mystagogic views on family were initiated in the apostolic times and contributed to the fact that in the patristic period, apart from structures of the official catechumenate, there was also family catechumenate. It was called domestic and lasted until the late Middle Ages. From the point of view of mystagogy, it should be emphasised that in the ancient Church the family was not only a place of sharing faith, but one where the liturgical life of the Church and formation of apostolic attitudes took place. ${ }^{4}$ This is confirmed in the patristic literature. For the first time, family was called a "small Church" (ecclesiola) by St. John Chrysostom. He claimed that the family comprises vital components of the Church: the presence of Christ, testimony of faith, the word of God, prayer, love and hospitality. ${ }^{5}$ Another great master of mystagogy, St. Augustine, referred to fathers as bishops, exhorting them to take care of faith in their homes. ${ }^{6}$ For these reasons in the patristic period, each time the "domestic Church" was mentioned, the emphasis was on the leading role of a father or a family patriarch for it corresponded to the superior authority of a bishop in his subordinate Church. ${ }^{7}$

After centuries of obscurity, after World War II, the notion of the "domestic Church" returned to theological-pastoral literature. It was developed in the teaching of the Second Vatican Council. ${ }^{8}$ The dogmatic constitution Lumen

Ocena pojęcia," in Malżeństwo i rodzina w świetle nauki Kościoła i wspótczesnej teologii, ed. Adam Ludwiuk Szafrański (Lublin: TN KUL, 1985), 242.

${ }^{3}$ Cf. Marek FiaŁKOwSKI, "Rodzina domowym Kościołem," in Teologia pastoralna, vol. 1, Teologia pastoralna fundamentalna, ed. Ryszard Kamiński (Lublin: Atla 2, 2000), 171.

${ }^{4}$ Cf. Piotr PORĘBA, "Wychowanie religijne $w$ rodzinie," in Wychowanie w rodzinie chrześcijańskiej, ed. Franciszek Adamski (Warsaw: Ośrodek Dokumentacji i Studiów Społecznych, 1973), 186.

${ }^{5}$ Cf. Stanisław DzIEKOŃSKI, Formacja chrześcijańska dziecka w rodzinie w nauczaniu Kościoła od Leona XIII do Jana Pawta II (Warsaw: Wydawnictwo UKSW, 2006), 185.

${ }^{6}$ Augustine, Sermo 94, in Patrologia Latina, 38:580-1; cited after ElżBIETA and MAReK MARCZEWSCY, "Kościół domowy,” 243.

${ }^{7}$ Ibid.

${ }^{8}$ It should be noted that the notions "little Church" and "domestic Church" appeared in pastoral letters of Polish bishops before the Second Vatican Council. They were used by Bishop Bernard Czapliński, Primate Cardinal Stefan Wyszyński, and Bishop Wilhelm Pluta. According to some Polish theologians (e.g., Czesław Bartnik), the term "domestic Church" was used in the conciliar documents under the influence of the Polish Episcopate, see Adam SKreCzKo, Troska Kościola 
Gentium referred to the family as "so to speak, the domestic church." Also, in the Decree on the Apostolate of the Laity Apostolicam actuositatem, one can find a conviction that the family by reason of the mutual affection of its members and the prayer that they offer to God "appears as the domestic sanctuary of the Church." 10 The founding reason for describing marriage and the family as "the domestic Church" is the fact that the Catholic marriage is a sacrament. Its very nature makes it a church-creating phenomenon. ${ }^{11}$ In such a perspective, the family becomes a community of salvation, and therefore identifies itself with the Church as a community of salvation. As such, in the teaching of the Council, the family is ultimately given the designation "domestic Church." 12

A statement made by Pope Paul VI during a general audience given on August 11, 1976, complemented the Council's teaching on the family as the "domestic Church." The pope offered an in-depth explanation of the concept of "domestic Church." He pointed out that due to its sacramental origin "the Christian family represents and creates the Church in miniature, construction 'element' of a one and universal Church, which as a whole is the Mystical Body of Christ." 13 Thus, the family elevates fragile and impermanent love to the level of supernatural love (Eph 5:21-33) and the law that binds together the family follows the model of unity of Christ and the Church.

The topic of the "domestic Church" was included in the teachings of John Paul II. In the post-synodal apostolic exhortation Christifideles laici, the pope clearly stated that the family is a natural and fundamental school for formation in the faith since it is the "domestic Church." The daily life of the Christian family comprises the first "experience of Church," intended to seek confirmation and

katolickiego w Polsce o matżeństwo i rodzinę w okresie Wielkiej Nowenny (1957-1966) (Białystok: Wydawnictwo Uniwersytetu w Białymstoku, 2002), 252.

${ }^{9}$ VATICAN II, Constitution Lumen gentium, December 21, 1964, no. 11.

${ }^{10}$ VATICAN II, Decree Apostolicam actuositatem, November 18, 1965, no. 11, http://www.vatican.va /archive/hist_councils/ii_vatican_council/documents/vat-ii_decree_19651118_apostolicam-actuositatem en.html.

${ }^{11}$ Building the Church takes place through marriage in a double sense. Marriage contributes to both qualitative and quantitative growth of the Church. It contributes to the growth of the Church ad extra (as external growth), and ad intra, understood as intensification of the internal life of the Church - see Jerzy GRZEŚKOwIAK, "Sakramentalność małżeństwa w świetle Adhortacji apostolskiej 'Familiaris consortio' Jana Pawła II," in Małżeństwo i rodzina w świetle nauki Kościoła $i$ wspótczesnej teologii, ed. Adam Ludwik Szafrański (Lublin: TN KUL, 1985), 85.

${ }^{12}$ Piotr PORĘBA, "Rodzina chrześcijańska „małym Kościołem”," in Wychowanie w rodzinie chrześcijańskiej, ed. Franciszek Adamski (Kraków: Wydawnictwo Apostolstwa Modlitwy, 1982), 182.

${ }^{13}$ For the Polish text, see PAUL VI, "Przemówienie na audiencji ogólnej (11.08.1976)," Wiadomości Archidiecezjalne Warszawskie 57, nos. 11-12 (1977): 280. 
development in a gradual, active and responsible process of the children's introduction into the wider ecclesial community. The aforementioned "gradual development of experience of Church" seems to refer directly to the mystagogic method. The effectiveness of mystagogy in developing a "sense of the Church" in children depends on the awareness of Christian spouses and parents that "their 'domestic church' participates in the life and mission of the universal Church."14

The novelty of the papal teachings of the family as the domestic Church can be best seen in the apostolic exhortation Familiaris consortio. The document highlights and systematizes the full definition of the term "domestic Church" in reference to the family. For John Paul II, it was apparent that there is a close relationship between the universal Church and the "domestic Church," which takes the form of a mutual dependency: "The Church thus finds in the family, born from the sacrament, the cradle and the setting in which she can enter the human generations, and where these in their turn can enter the Church." 15 Between the Church and the family there are strong bonds that establish the latter as a "Church in miniature," in that the family is a living image and historical representation of the mystery of the Church. ${ }^{16}$ A church-creating function of the family can be defined using categories of fundamental functions of the Church that realises it in the world. The Church realises itself by fulfilling the prophetic, priestly and royal functions of Christ. This triple vocation, resulting from the sacramental bond between Christian spouses and Christ the Prophet; and the Priest and the King, makes the family a believing and practicing community - a community of dialogue with God, and a community in service of humanity. ${ }^{17}$ The Christian family is called upon to actively and responsibly take part in the mission of the Church in a way that is original and specific, by defining itself as an intimate community of life and love in the service of the Church. The family's sharing in the Church's mission should follow a community pattern; the spouses as a couple and the parents and children as a family - all must live their service to the Church and to the world. ${ }^{18}$

The mystagogic view of the nature and vocation of the Christian family suggested by John Paul II highlights the Church's spiritual and mystic character, transcending social and psychological patterns. Since the Christian family

\footnotetext{
${ }^{14}$ John PaUl II, Apostolic Exhortation Christifideles laici, December 30, 1988, no. 62 (see the English version on www.vatican.va).

${ }^{15}$ JoHN PAUL II, Apostolic Exhortation Familiaris consortio, November 22, 1981, no. 15 (see the English version on www.vatican.va).

${ }^{16}$ Ibid., no. 49.

${ }^{17}$ Ibid., nos. 49-64.

${ }^{18}$ Ibid., no. 50.
} 
constitutes a reality where the Church is created and actualized, one cannot perceive the family exclusively as the smallest unit of the Church. ${ }^{19}$ Special relations between the Christian family and the Church should be defined as tasks resulting from love, including forming a community of persons, serving life, participating in the development of community, and sharing in the life and mission of the Church. ${ }^{20}$

From the perspective of a mystagogic dimension of the Christian formation, a vital role is played by the last task, which is a realisation of a prophetic, priestly and kingly function. ${ }^{21}$ It manifests itself, among other things, in educational activities of the mystagogic character which are to be carried out as a part of family catechesis. The family home is the first school of Christian life in which a child learns brotherly love, especially how to worship God by prayer and sacrifice of one's life. ${ }^{22}$

\section{AIMS AND TASKS OF THE FAMILY CATECHUMENATE}

The Declaration on Christian Education Gravissimum educationis states that the principal goal of Christian education is that the baptized, while they are gradually introduced to the knowledge of the mystery of salvation, become ever more aware of the gift of Faith they have received. Accordingly, they learn how to worship God, the Father, in spirit and truth (cf. John 4:23) especially in liturgical action, and conform their personal lives according to the new man created in justice and holiness of truth (Eph 4:22-24). At the same time, a conviction is expressed that since parents have given children their life, they are bound by the most serious obligation to educate their offspring and therefore must be recognized as the primary and principal educators. The

\footnotetext{
${ }^{19}$ DZIEKOŃSKI, Formacja chrześcijańska dziecka, 194.

${ }^{20}$ Cf. John Paul II, Christifideles laici, no. 17.

${ }^{21}$ Cf. Anna LisKowACKA, "Rodzina chrześcijańska w życiu i posłannictwie Kościoła w świetle Adhortacji apostolskiej Jana Pawła II 'Familiaris consortio,"” in Ewangelizacja wspólnoty matżeńskiej i rodzinnej. Program Duszpasterski na rok 1993/1994, ed. Eugeniusz Szczotok and Anna Liskowacka (Katowice: Księgarnia św. Jacka, 1993), 296-97.

${ }^{22}$ Cf. Catechism of the Catholic Church (Vatican City: Libreria Editrice Vaticana, 2003), no. 1657 (see the English version on www.vatican.va); cf. Roman BuchtA, Mistagogia w polskiej refleksji i praktyce katechetyczno-duszpasterskiej po II Soborze Watykańskim (Katowice: Księgarnia św. Jacka, 2017), 440-46.
} 
document makes it clear that "this role in education is so important that only with difficulty can it be supplied where it is lacking." 23

However, in pastoral practice we face a serious problem. As Father Franciszek Blachnicki rightly observed, parents in general have lost awareness of their responsibility for the religious growth of their children. They believe that their duty in this respect is fulfilled solely by the fact of "sending children to religion classes." ${ }^{24}$ In this context, Blachnicki expressed a conviction that the faith of a child cannot develop fully if it is not supported by faith and religious life of its closest background. Actualization of religious attitudes among children takes place through interaction with the religious attitude of adults with whom these children are closely related to by love or with whom have everyday contact. Blachnicki was absolutely certain that "effort made by official catechists of the Church to shape religious attitude will be futile, if it is not supported by influence of religious family background. Influence of the background will always be stronger than influence of the best catechesis." ${ }^{25}$ In view of the above assumptions, he drew important conclusions for catechesis and pastoral work. He concluded that if the major subject of catechesis and Christian education is a family of believers, the major focus of catechetic formation - without neglecting catechetical activities so far-should be shifted on the reconstruction of the Christian family community. ${ }^{26}$

A precondition for implementing the mystagogic dimension of education in the family is return to the family catechumenate, understood as a natural consequence of infant baptism. ${ }^{27}$ The Christian family is to take up tasks and objecttives of the catechumenate in its own proper way. ${ }^{28}$ The principal aim is to bring children, as they develop, to a deeper knowledge of the mysteries of faith, deepen their personal relation with Christ and their vocation in the Church. ${ }^{29}$

${ }^{23}$ VATICAN II, Declaration on Christian Education Gravissimum educationis, October 28, 1965, no. 3 (see the English version on www.vatican.va).

${ }^{24}$ Franciszek BlACHNICKI, "Katechumenat na dzisiejszą godzinę,” Tygodnik Powszechny, no. 24 (1973): 2.

${ }^{25}$ Ibid.

${ }^{26}$ Franciszek BlachNicki, Pisma katechetyczne, vol. 2, Katechetyka fundamentalna, ed. Marek Marczewski, Roman Murawski, and Kazimierz Misiaszek (Warsaw: Wydawnictwo Salezjańskie, 2006), 223.

${ }^{27}$ Franciszek BLACHNICKI, Sympatycy czy chrześcijanie? Katechumenat na dzisiejsza godzinę (Kraków: Światło-Życie, 2003), 78-92.

${ }^{28}$ Cf. Józef WILK, "Rola katechumenatu rodzinnego w inicjacji eucharystycznej dziecka," Roczniki Teologiczno-Kanoniczne 23, no. 6 (1976): 63-75.

${ }^{29}$ Cf. Helena SŁotwiŃSKA, "Katechumenat rodzinny jako miejsce formacji do wiary dojrzałej w ujęciu Sługi Bożego ks. Franciszka Blachnickiego," in Ksiądz Franciszek Blachnicki - katechetyk 
The first most important task in this respect is the creation of an atmosphere of authentic religious life. It influences the shaping of attitudes much more than learning about and shaping religious notions. Family catechesis should not be understood as didactics. The mystagogic dimension of education in the family is implemented when, on the occasion of family events or religious holidays, one explains their Christian or religious meaning. ${ }^{30}$ In other words, everyday family life is to become catechesis. As such, everything that takes place in the family becomes a natural factor in shaping religious life, and the synthesis of faith and life arises more spontaneously and naturally. The richness of the catechumenate experience confirms that education takes place not so much by words, but by deeds and, above all, love and an attitude of servitude to others. Only when these conditions are met it is possible to experience the truth about God's love for man on an existential level. ${ }^{31}$

Everyday family life is often children's first experience of the Church. Ideally, this experience gradually deepens and broadens over time, with children becoming more active in local church community life. One condition to fostering a proper "sense of the Church" in children is parents' involvement in children's participation in catechetic and educational activities in the mission of the Church. Achievement of this aim requires specific goals that have a special importance for mystagogy:

- conveying the real image of God,

- enabling basic religious experiences,

- creating initial religious notions,

- shaping a mentality of faith that will lead to a deep and personal relationship with God,

- introducing the word of God,

- teaching to pray,

- introducing the liturgical year,

- liturgical formation,

- introducing to ecclesial community life,

- integrating life with faith. ${ }^{32}$

i pastoralista. W dwudziestą rocznicę śmierci Stugi Bożego, ed. Roman Buchta (Katowice: Księgarnia św. Jacka, 2009), 191.

${ }^{30}$ Cf. John Paul II, Apostolic Exhortation Catechesi tradendae, October 16, 1979 (Vatican City: Libreria Editrice Vaticana, 1979), no. 68 (see the English version on www.vatican.va); CONGREGATION FOR THE ClERGY, General Directory for Catechesis (Vatican City: Libreria Editrice Vaticana, 1997), no. 226.

${ }^{31}$ Cf. Elżbieta OsEwSKA, “Komunikacja wiary w rodzinie,” Katecheta 39, no. 3 (1995): 141.

${ }^{32}$ Cf. Elżbieta OsEwSKA, "Kierunki współczesnej katechezy rodzinnej odczytane w literaturze pedagogiczno-katechetycznej," in Drogi katechezy rodzinnej, ed. Elżbieta Osewska and Józef Stala (Poznań: Wydawnictwo Świętego Wojciecha, 2002), 37. 
The formative tasks of mystagogic character are as follows:

- explaining the meaning of life events,

- testimony of life given by parents,

- deeper introduction to Christian life, understood as awakening of the sense of God,

- first steps in prayer,

- education of moral conscience,

- forming the Christian sense of human love, understood as a reflection of the love of God and Father. ${ }^{33}$

The mystagogic dimension of education in the family community, perceived holistically, is implemented as introducing children to the idea of life by the word of God (prophetic function); and participation in the priestly functions of liturgy (priestly function) and practices of Christian life (kingly function).

\subsection{Formation in the family to assume the prophetic function}

The mystagogic dimension of education in assuming the prophetic function is realised when parents become the heralds and preachers of the Gospel for their children. Due to the unique character of family community relations, the Good News is transmitted not only through words, but by the example of one's own life. Through baptism, confirmation and the sacrament of matrimony, parents are the first catechists of their children. ${ }^{34}$ Similarly, the family, perceived as a catechumenal community, is the first school of faith for children. Learning about faith is not simply about learning formulas from catechism; rather, it involves solving life's problems in light of the word of God. ${ }^{35}$ Disseminating faith within the family can be also described as "handing over the keys" to historic and salvific interpretations and biblical assessments of life experience. ${ }^{36}$ It is important to note that family catechesis precedes, accompanies and enriches all other forms of catechesis; and its relation to family life adds to it a practical dimension. ${ }^{37}$ Faith may take different forms, leading to simple religious actions, notions, and religious language as a basis for systematic learning of the truths of

${ }^{33}$ Cf. Kazimierz MisiaszeK, "Katecheza rodzinna czy katecheza rodzin? Propozycje dla polskiego duszpasterstwa," in OSEWSKA and STALA, Drogi katechezy rodzinnej, 46.

${ }^{34}$ Cf. Józef Stala, "Rodzina środowiskiem katechezy," in OSEwSKa and Stala, Drogi katechezy rodzinnej, 210.

${ }^{35}$ As Słotwińska emphasizes the fact that solving life problems does not stop at learning the rules of Christian life, but should lead to their application in life, see Helena SŁOTwiŃsKA, "Katechumenat rodzinny jak miejsce formacji," 196.

${ }^{36}$ Cf. OsEwSKA, "Komunikacja wiary w rodzinie," 142.

${ }^{37}$ Cf. John Paul II, Catechesi tradendae, no. 68. 
faith. Parents who consciously assume their duty to introduce children to the mystery of the Church use every opportunity to talk with their children about religious matters. This applies especially to situations when children experience their first religious doubts or are faced with a conflict of rules of the faith and Christian morality in everyday life. To cope with these tasks, parents and other family members require knowledge of the truths of faith and expand this knowledge regularly. This is why the family as the domestic Church should be a place of regular reading and contemplation of Sacred Scripture, as well as reading educational books and religious press. ${ }^{38}$

The Second Vatican Council underlined the pre-eminent role of the word of God in the life of the Church. John Paul II referred to this in his apostolic letter Novo millennio ineunte. Setting up a pastoral programme for the new millennium he reminded us that "above all the work of evangelization and catechesis is drawing new life from attentiveness to the word of God. This development needs to be consolidated and deepened, also by making sure that every family has a Bible." ${ }^{39}$ Developing this papal thought one can say, that not only should every family have a Bible at home, but - following John Paul II's order-this Bible should be read and contemplated. ${ }^{40}$ In this way parents assist their children in shaping the biblical image of God, introduce them to the mystery of God and His works, which He does and will do for the sake of man and his salvation. ${ }^{41}$

The parents' ministry of catechesis is not limited to the period of childhood. In an appropriate way it should be offered to children during adolescence and youth, when the children, as often happens, go through the turbulent period of rebellion and contestation. It is then that one is faced with a possibility

\footnotetext{
${ }^{38}$ FiAŁKOWSKI, "Rodzina domowym Kościołem," 173.

39 John PAUl II, Apostolic Letter Novo millennio ineunte, June 1, 2001, no. 39 (see the English version on www.vatican.va).

${ }^{40}$ Czesław Murawski, "Rodzina środowiskiem katechezy," in Osewska and Stala, Drogi katechezy rodzinnej, 211.

${ }^{41}$ Parents' tasks in the process of shaping the image of God, and possibilities of pastoral support for them are analysed by Anna E. Klich. The author emphasises the importance of catechesis for parents before baptism of their children, catechesis for parents of the first Communion children and meetings for parents of adolescents before the sacrament of confirmation. A manifestation of care and responsibility from the side of pastors and catechists is "conducting these meetings in a prayerful and formative way, as opposed to purely formative one. It is necessary to raise awareness among parents, so that they participate in transmitting the image of themselves, of the world and God" - Anna E. Klich, "Współpraca z rodzicami w kształtowaniu biblijnego obrazu Boga," in W poszukiwaniu katechezy rodziców. Studium teoretyczno-empiryczne, ed. Józef Stala and Elżbieta Osewska (Tarnów: Biblos, 2007), 147-61.
} 
to reject the Christian faith received earlier in life. ${ }^{42}$ In this period young people need clear guidelines and reliable authorities based on authentic Christian life. ${ }^{43}$ This is why proclaiming Gospel in the family should be reflected in the everyday life of the family and in the family's testimony of faith, which is a manifestation of the educational function carried out by the family as the domestic Church. This testimony refers to, in the first place, the family circle, which later on should be transcended. The family is a practical school of the apostolate, ${ }^{44}$ understood in its internal and internal dimension. ${ }^{45}$ Entire family life should be characterised by missionary zeal, for "the Church of the home is also called to be a luminous sign of the presence of Christ and of His love for those who are "far away'." This is implied for families who do not yet believe, and for those Christian families who no longer live in accordance with the faith that they once received. The Christian family is called to enlighten "by its example and its witness ... those who seek the truth." 46

\subsection{Family formation to take up a priestly function}

A duty to educate children to take up a priestly function has been justified in the documents of the second Vatican Council. It was reminded to the faithful that upon the power of the common priesthood all the people of God should participate in the triple mission of Christ. Married and family life, with its context of everyday occupations, may become the source of spiritual sacrifice offered to God through Jesus Christ. ${ }^{47}$ The sacramental grace of matrimony bestows the family community with sanctifying grace. By the grace of the Holy Spirit, common works done for the family, even humble and menial ones, generate supernatural effects. ${ }^{48}$ The sacrament of matrimony comprises both a gift and responsibility for spouses. They receive grace for each day and moral obligation to change their entire life into perpetual "spiritual sacrifice" (Rom 12:1). ${ }^{49}$

The mystagogic dimension of education towards priestly ministry is realised, among other things, through a unique approach of parents to children. Not only

\footnotetext{
${ }^{42}$ Cf. John Paul II, Familiaris consortio, no. 53.

${ }^{43}$ GRZEŚKOWIAK, "Sakramentalność małżeństwa," 88.

${ }^{44}$ Cf. VATICAN II, Apostolicam actuositatem, no. 30.

${ }^{45}$ Jan KŁYS, "Rodzina katolicka i środowisko jako teren apostolstwa świeckich,” in Nowa ewangeliizacja u progu Trzeciego Tysiąclecia. Program duszpasterski na rok 2000/2001, ed. Eugeniusz Szczotok, Roman Kempny, and Anna Liskowacka (Katowice: Księgarnia św. Jacka, 2000), 331-35.

${ }^{46}$ John PaUl II, Familiaris consortio, no. 54.

${ }^{47}$ Cf. Vatican II, Lumen Gentium, no. 34.

${ }^{48}$ LiskowaCKA, "Rodzina chrześcijańska," 307.

${ }^{49}$ MurawSKI, "Rodzina środowiskiem katechezy," 212.
} 
do parents share their knowledge of God with their children but represent God directly to children and use His authority to exercise their parental authority. ${ }^{50}$ The priestly function of Christ is made present to the fullest in "the domestic sanctuary of the Church" through sacramental life and prayer. Intensity of receiving sacraments in adult life depends on the foundations laid in the domestic Church. ${ }^{51}$ It is the family that is responsible for an appropriate introduction of a child to sacramental life and life of prayer. ${ }^{52}$ The family community, living within the framework of the church year and according to a weekly Sundayobservance rhythm, has a chance to introduce its members to the liturgy of the Church in a natural way. Faced with the mystery of the salvific works of Jesus Christ made present in the Church, children, little by little, enter the double dimension of liturgy through their introduction to the sanctifying works of God and the shaping of an attitude of worship. ${ }^{53}$ It calls for the testimony of a sacramental life and parents, without the above-mentioned actions, will ultimately present empty gestures deprived of the power of internal influence. ${ }^{54}$

Not only does the Christian family participate in the liturgy of the universal Church but it celebrates the so-called "liturgy of the domestic Church." It is in this liturgy that sanctification and evangelisation of the family takes place. The liturgy of the domestic church is closely related to the liturgy of the universal Church, as it is its source and final destination. ${ }^{55}$ All members of the family participate in the liturgy of the domestic Church when they gather around a home altar and pray together, read the Bible and meditate. This is a special place at home which, owing to its purpose and symbolism, becomes a testimony of faith of the family and a discrete reminder of the spirit the family should live in if it desires to represent the domestic Church. ${ }^{56}$ The home liturgy comprises all customs related to the church year, church holidays and family events.

\footnotetext{
${ }^{50}$ LISKOWACKA, "Rodzina chrześcijańska," 308.

${ }^{51}$ Cf. Polish Bishops' CONFEREnCE, Dyrektorium katechetyczne Kościoła katolickiego w Polsce [Catechetical Directory of the Catholic Church in Poland] (Kraków: Wydawnictwo WAM, 2001), no. 25.

52 Roman BuchtA, "Przygotowanie dzieci do Pierwszej Komunii Świętej w wieku przedszkolnym jako droga formacji rodzin - w świetle zaleceń pastoralnych biskupów katowickich,” in Eucharystia pokuta i pojednanie w katechezie. Problemy i wyzwania, ed. Józef Stala (Kielce: Jedność, 2007), 205-20.

53 OSEWSKA, "Komunikacja wiary w rodzinie," 142.

${ }^{54}$ The importance of an example of the sacramental life of all family members as an indispensable foundation of introducing children to the mystery of God has been analysed by Józef Stala; see Józef STALA, $W$ kierunku integralnej edukacji religijnej $w$ rodzinie (Próba refleksji nad nauczaniem Jana Pawła II w kontekście polskich uwarunkowań) (Tarnów-Lublin: Wydawnictwo Polihymnia, 2010), 208-24.

${ }^{55}$ JoHn PAUL II, Familiaris consortio, no. 61.

${ }^{56}$ Józef WysOcki, Rytuat rodzinny. Aby rodzina była bardziej Kościołem (Olsztyn: Warmińskie Wydawnictwo Diecezjalne, 1990), 21-22.
} 
It includes sacramentals, especially blessings and consecrations which, in the domestic Church under specific circumstances, can be celebrated by parents who adopt a function of celebrants of the home sanctuary. ${ }^{57}$

An extremely important element of family mystagogy is sitting around a common table, which brings all family members and guests together. A family table in its symbolism refers to the eucharistic table. Jesus Christ, during the Last Supper, established the Eucharist in a family way. This is why parents should, in a natural way, point at the importance of sitting around a table and having a meal together to share both food and love. The task of the family catechumenate, in which a child is getting ready for the first Communion, is to shape a communal attitude and an ability to share food, life and mutual service at the table. Thanks to a consistent attitude of the family, a child should discover that just as his daily food nurtures his or her physical strength, the Eucharist is the source of his spiritual strength. In order to really experience the gift of Eucharist, which is to use all its fruits, it is necessary to prepare oneself. This preparation is understood as a transition from the visible to the invisible, from the sign to the reality it signifies, from sacraments to mysteries. The mystagogic dimension of formation to a priestly function is realised in the family not so much by checking the knowledge of the catechism regarding the Eucharist, but by showing children its value in everyday life. This is emphasised especially through a full participation of the family in the Eucharist on Sundays and church holidays. ${ }^{58}$ Communal participation of the entire family in the Eucharist should be understood in relation with "spiritual sacrifice" of children and parents, as offered to God through Christ every day. Fulfilling parental duties, daily mutual service and forgiving love, in other words the entire reality of family life, becomes "spiritual sacrifices acceptable to God through Jesus Christ" (1 P 2:5), which in Sunday Eucharist receives a sacramental character. Spiritual sacrifices are offered to God once again by "the priestly family" in communion with the bloodless sacrifice of Christ. ${ }^{59}$

By reason of their participation in the common priesthood, parents have the special mission and "the specific responsibility of educating their children in prayer, introducing them to gradual discovery of the mystery of God and to personal dialogue with Him." ${ }^{60}$ The mission will be fulfilled best by personal example since "only by praying together with their children can a father and

\footnotetext{
${ }^{57}$ FiAŁKOWSKI, "Rodzina domowym Kościołem," 175-76.

${ }^{58}$ STALA, W kierunku integralnej edukacji, 216.

59 GRZEŚKOWIAK, "Sakramentalność małżeństwa," 89.

${ }^{60}$ John PAUl II, Familiaris consortio, no. 60.
} 
mother ... penetrate the innermost depths of their children's hearts and leave an impression that the future events in their lives will not be able to efface." In spite of the Pope's guidelines, education in prayer is very difficult, since in many homes of the baptised the practice of prayer is extinct. Therefore, children cannot see the purpose of prayer and do not feel the need to pray. Without prayer the Christian family lacks its major feature. If the family really is to be the "domestic Church," it must return to the practice of common prayer that is close to the family's heart. ${ }^{62}$ The content of family prayer should include the everyday life of the family's community, its joys and sorrows, successes and problems. It should also include important matters of the entire world. By presenting everyday life to God in prayer, the family sanctifies it and fulfills its priestly function in its specific way. ${ }^{63}$ Each family should work out its own praying style, starting from the easiest acts of worship and thanksgiving to a personal meeting with God. ${ }^{64}$ While we perceive the Christian family as an entity that participates in the mission of the Church, the following thought of John Paul II is worth reminding: "prayer constitutes an essential part of Christian life... Far from being a form of escapism from everyday commitments, prayer constitutes the strongest incentive for the Christian family to assume and comply fully with all its responsibilities." 65 This task is linked with the third major function exercised by the family as the "domestic Church" - the kingly function.

\subsection{Family formation to take up the kingly function}

The kingly function is an indispensable completion of the former two, for it is impossible to talk about realisation of the prophetic and priestly function in the family without linking it with the attitude of service, which is the best exemplification of the kingly function. The Christian couple should practice the attitude of service which, if accepted by the entire family, is supposed to draw brothers toward the King, whom to serve means to reign. ${ }^{66}$ The family's

\footnotetext{
${ }^{61}$ Cf. ibid.

${ }^{62}$ Cf. Jo Hermans, "Wychowanie liturgiczne a mistagogia w rodzinie," in Ewangelizacja wspólnoty małżeńskiej i rodzinnej. Program duszpasterski na rok 1993/1994, ed. Eugeniusz Szczotok and Anna Liskowacka (Katowice: Księgarnia św. Jacka, 1993), 354.

${ }^{63}$ Cf. Franciszek KAMECKI, "Ważniejsze zadania katechetyczne (po przeczytaniu adhortacji Jana Pawła II 'Familiaris consortio')," Katecheta 26, no. 4 (1982): 149.

${ }^{64}$ Cf. MuRAwSKI, "Rodzina środowiskiem katechezy," 215; WILK, "Rola katechumenatu rodzinnego," 73-74.

65 JoHn PAUL II, Familiaris consortio, no. 62.

${ }^{66} \mathrm{Cf}$. ibid., no. 63.
} 
participation in the kingly function defines three circles of the service attitude: serving the family, serving every human being, and serving the entire creation. The source of responsibility of the family is in the enumerated circles in baptism, confirmation, and the sacrament of matrimony. By accepting these sacraments the spouses receive, from Christ, the kingly power to serve people and conquer the reign of sin in themselves (Romans 6:12). ${ }^{67}$

Exercising the kingly function in the family manifests itself mainly through love that should become a determinant of everyday life. Pursuant to God's plan, spousal love is the image of Christ's love to the Church. The spousal community transforms into family communion when parents transfer the gift of life to their children. Parental love requires the attitude of sacrifice, especially during the long years of upbringing children. However, only in the atmosphere of parental love can children discern their vocation and become mature enough to exercise the kingly function. The kingly mission of the Christian family develops through daily shaping and caring for mutual love of all its members. It manifests itself in patience and kindness, the spirit of mutual service and care, especially for the sick in the family, the disabled and weakened by old age. ${ }^{68}$

The family living by the love to God and the neighbour cannot be focused on a narrow horizon of its own matters. Due to its vocation to participate in the mission of the Church, the family should notice and open up to others. The family catechumenate's task is to teach children the attitude of respect, selfless help and empathy for those in need. What is indispensable in this respect is motivating children and showing them specific possibilities of providing help according to their abilities, such as praying for those in need, visiting the sick, saving small amounts of money for poor parishioners or victims of natural disasters. The family that takes up charitable work is a beautiful testimony of love and solidarity. By practicing charity, the family gets a chance to shape the attitude of ministerial love (caritas) ${ }^{69}$ in children and all its members.

The kingly vocation of the family comprises a broad scope of social, political, economic, cultural, national, and international problems. The family is authorised to take up these problems responsibly, since the sacrament of matrimony obliges Christian spouses and parents to live their vocation as lay people. This means to "seek the kingdom of God by engaging in temporal affairs and by ordering them according to the plan of God." ${ }^{, 70}$ It seems that the scope

\footnotetext{
${ }^{67}$ MURAWSKI, "Rodzina środowiskiem katechezy,” 216.

${ }^{68}$ Cf. ibid., 217.

${ }^{69}$ Cf. FiaŁKOWSKI, "Rodzina domowym Kościołem," 175-76.

${ }^{70}$ John PAUl II, Familiaris consortio, no. 47.
} 
of upbringing children to exercise the kingly mission should be broadened to include the active care of the family for the entire natural environment that today undergoes a process of perpetual degradation. ${ }^{71}$ Pope Francis committed the Church to take measures in this respect in his encyclical Laudato si ${ }^{72}$

It is impossible to neglect one more dimension of the kingly function in the family that is exercised by seeking personal holiness of life. It requires a constant effort and self-improvement of every member of the family. It is related to conquering evil and egoism, fighting sins and faults, and the ability to stand for truth and justice not only in the family environment, but in the social environment, at work and at school. Exercising Christian lifestyle, followers of Christ are summoned to take up His mission, fill the world with spiritual values and build the civilization of love. By its daily life, seeking holiness, practicing love and patience and fighting weaknesses, the family as the "domestic Church" draws the doubting and non-believers to Christ and the community of the Church. ${ }^{73}$ Daily care for faithfulness to the kingly vocation of the family defines further detailed tasks of education in the family catechumenate. ${ }^{74}$

The effectiveness of Christian education calls for integrated measures as taken by all circles responsible for education in faith. An exceptional and irreplaceable role in this respect is exercised by the family. If we take a comprehensive look at contemporary conditions of catechetic ministry, it seems fair to say that the postulate to appreciate the mystagogic dimension of formation (present in Polish catechetic and pastoral reflection for years) is applied more and more in guidelines of the latest catechetic documents. Both the core curriculum for Catholic catechesis and the curriculum for Roman Catholic religion instruction in schools and kindergartens, introduced in 2020/2021, emphasise the necessity to cooperate in the area of educating the family, parish and school. ${ }^{75}$ As we read in the curriculum for Roman Catholic religious instruction,

\footnotetext{
${ }^{71}$ MURAWSKI, "Rodzina środowiskiem katechezy,” 216.

${ }^{72}$ See Francis, Encyclical Letter Laudato si', May 24, 2015 (Vatican City: Libreria Editrice Vaticana, 2015); see the English version on www.vatican.va.

${ }^{73}$ FiaŁKOWSKI, "Rodzina domowym Kościołem," 176.

${ }^{74}$ Cf. BuchtA, Mistagogia w polskiej refleksji, 446-57.

${ }^{75}$ Cf. Polish Bishops' Conference, Podstawa programowa katechezy Kościoła katolickiego w Polsce (Częstochowa: Edycja Świętego Pawła, 2018), 25-26, 48-50, 92-93, 136-37, 161-64; cf. Catholic Education Commission of the Polish Bishops' Conference, Program nauczania
} 
"there are parents who are the first educators, and the family creates the first community of maturation and growth of faith. This smallest and the most natural community should reflect various aspects and functions of life of the entire." 76 The new curriculum points at major directions of catechetical-and-pastoral initiatives and emphasises the necessity to strengthen the awareness that the family is summoned to pray together daily, read the word of God and Eucharistic Communion. Preparation of catechetical meetings in parishes should lead to family catechesis, without which it is impossible to speak of a full preparation for Christian life. In turn, meetings with parents should become a part of the framework of catechetical initiatives. Due to their educational nature, such meetings should support parents in their formative tasks. ${ }^{77}$ The same aproach to mystagogic dimension of Christian formation in the family community is adopted in the pastoral program of the Church in Poland. ${ }^{78}$ Therefore, we can hope that postulate guidelines included in the documents will be implemented in daily catechetical-and-pastoral practice. ${ }^{79}$

\section{BIBLIOGRAPHY}

BlachNICKI, Franciszek. "Katechumenat na dzisiejszą godzinę." Tygodnik Powszechny, no. 24 (1973): 1-2.

Blachnicki, Franciszek. Pisma katechetyczne. Vol. 2, Katechetyka fundamentalna, edited by Marek Marczewski, Roman Murawski, and Kazimierz Misiaszek. Warsaw: Wydawnictwo Salezjańskie, 2006.

BlachNICKI, Franciszek. Sympatycy czy chrześcijanie? Katechumenat na dzisiejsza godzinę. Kraków: Światło-Życie, 2003.

religii rzymskokatolickiej w przedszkolach i szkołach (Częstochowa: Edycja Świętego Pawła, 2018), 34-35, 78-82, 154-56.

${ }^{76}$ Ibid., 78.

${ }^{77}$ Ibid.

${ }^{78}$ Cf. Roman BuchtA, "Wprowadzenie," in Wielka Tajemnica wiary. Program duszpasterski Kościoła w Polsce na rok 2019/2020. Zeszyt katechetyczny, ed. Roman Buchta and Kazimierz Misiaszek (Katowice: Instytut Gość Media, 2019), 5-6.

${ }^{79}$ The Second Synod of Archdiocese of Katowice, when referring to Polish binding catechetical documents, ordered the introduction of catechesis for adults in every parish, with special emphasis on catechesis for parents of children preparing for the sacraments of Christian initiation. One of the guidelines is catechesis for parents of children and adolescents at all levels of education. Catechetical meetings with parents are to be of mystagogical character, aiming at active and full participation of the family in Eucharist; cf. Wstuchani w Ducha. Uchwaty II Synodu Archidiecezji Katowickiej (Katowice: Księgarnia św. Jacka, 2016), nos. 271, 272, 277, and 278. 
BuCHTA, Roman. Mistagogia w polskiej refleksji i praktyce katechetyczno-duszpasterskiej po II Soborze Watykańskim. Katowice: Księgarnia św. Jacka, 2017.

BuchTA, Roman. "Przygotowanie dzieci do Pierwszej Komunii Świętej w wieku przedszkolnym jako droga formacji rodzin - w świetle zaleceń pastoralnych biskupów katowickich.” In Eucharystia - pokuta i pojednanie w katechezie. Problemy $i$ wyzwania, edited by Józef Stala, 205-20. Kielce: Jedność, 2007).

BuchtA, Roman. "Wprowadzenie." In Wielka Tajemnica wiary. Program duszpasterski Kościoła w Polsce na rok 2019/2020. Zeszyt katechetyczny, edited by Roman Buchta and Kazimierz Misiaszek, 7-8. Katowice: Instytut Gość Media, 2019.

Catechism of the Catholic Church. Vatican City: Libreria Editrice Vaticana, 2003. www.vatican.va/ archive/eng0015/_INDEX.HTM.

Catholic Education Commission of the Polish Bishops' Conference. Program nauczania religii rzymskokatolickiej w przedszkolach $i$ szkołach [Curriculum for Roman Catholic religious instruction in schools and kindergartens]. Częstochowa: Edycja Świętego Pawła, 2018.

Congregation for Clergy. General Directory for Catechesis. Vatican City: Libreria Editrice Vaticana, 1998.

DZIEKOŃSKI, Stanisław. Formacja chrześcijańska dziecka $w$ rodzinie w nauczaniu Kościoła od Leona XIII do Jana Pawta II. Warsaw: Wydawnictwo UKSW, 2006.

FIAŁKOWSKI, Marek. "Rodzina domowym Kościołem.” In Teologia pastoralna. Vol. 1, Teologia pastoralna fundamentalna, edited by Ryszard Kamiński, 171-76. Lublin: Atla 2, 2000.

FRANCIS. Encyclical Letter Laudato si', May 24, 2015. Vatican City: Libreria Editrice Vaticana, 2015. http://www.vatican.va/content/francesco/en/encyclicals/documents/papa-francesco_20150524 enciclica-laudato-si.html.

GRZEŚKOWIAK, Jerzy. "Sakramentalność małżeństwa w świetle Adhortacji apostolskiej 'Familiaris consortio’ Jana Pawła II.” In Małżeństwo i rodzina w świetle nauki Kościoła i wspótczesnej teologii, edited by Adam Ludwik Szafrański, 57-89. Lublin: TN KUL, 1985.

Hermans, Jo. "Wychowanie liturgiczne a mistagogia w rodzinie." In Ewangelizacja wspólnoty matżeńskiej i rodzinnej. Program duszpasterski na rok 1993/1994, edited by Eugeniusz Szczotok and Anna Liskowacka, 349-61. Katowice: Księgarnia św. Jacka, 1993.

JoHn PAUL II. Apostolic Exhortation Catechesi tradendae, October 16, 1979. Vatican City: Libreria Editrice Vaticana, 1979. www.vatican.va/content/john-paul-ii/en/apost_exhortations/documents/ hf_jp-ii_exh_16101979_catechesi-tradendae.html.

John PAUl II. Post-Synodal Apostolic Exhortation Christifideles laici, December 30, 1988. Vatican City: Libreria Editrice Vaticana, 1988. www.vatican.va/content/john-paul-ii/en/apost exhortations/ documents/hf jp-ii exh 30121988 christifideles-laici.html.

John PAul II. Apostolic Exhortation Familiaris consortio, November 22, 1981. Vatican City: Libreria Editrice Vaticana, 1981. www.vatican.va/content/john-paul-ii/en/apost_exhortations/ documents/hf_jp-ii_exh_19811122_familiaris-consortio.html.

John PaUl II. Apostolic Letter Novo millennio ineunte, June 1, 2001. Vatican City: Libreria Editrice Vaticana, 2001. www.vatican.va/content/john-paul-ii/en/apost letters/2001/documents/ hf_jp-ii_apl_20010106_novo-millennio-ineunte.html.

KAMECKI, Franciszek. "Ważniejsze zadania katechetyczne (po przeczytaniu adhortacji Jana Pawła II 'Familiaris consortio')." Katecheta 26, no. 4 (1982): 145-51. 
KLICH, Anna E. “Współpraca z rodzicami w kształtowaniu biblijnego obrazu Boga.” In W poszukiwaniu katechezy rodziców. Studium teoretyczno-empiryczne, edited by Józef Stala and Elżbieta Osewska, 147-61. Tarnów: Biblos, 2007.

KŁYS, Jan. "Rodzina katolicka i środowisko jako teren apostolstwa świeckich.” In Nowa ewangelizacja u progu Trzeciego tysiaclecia. Program duszpasterski na rok 2000/2001, edited by Eugeniusz Szczotok, Roman Kempny, and Anna Liskowacka, 327-38. Katowice: Księgarnia św. Jacka, 2000).

LISKOwACKA, Anna. "Rodzina chrześcijańska w życiu i posłannictwie Kościoła w świetle Adhortacji apostolskiej Jana Pawła II 'Familiaris consortio'.” In Ewangelizacja wspólnoty matżeńskiej i rodzinnej. Program Duszpasterski na rok 1993/1994, edited by Eugeniusz Szczotok and Anna Liskowacka, 288-313. Katowice: Księgarnia św. Jacka, 1993.

MARCZEwSCY, Elżbieta, Marek. “'Kościół domowy’. Ocena pojęcia.” In Matżeństwo i rodzina $w$ świetle nauki Kościoła $i$ współczesnej teologii, edited by Adam Ludwik Szafrański, 241-54. Lublin: TN KUL, 1985.

MisiaszeK, Kazimierz. "Katecheza rodzinna czy katecheza rodzin? Propozycje dla polskiego duszpasterstwa." In OsewSKA and STALA, Drogi katechezy rodzinnej, 39-51.

Murawski, Czesław. "Rodzina środowiskiem katechezy.” In OsewSKa and Stala, Drogi katechezy rodzinnej, 207-18.

OsewsKa, Elżbieta, and Józef Stala, eds. Drogi katechezy rodzinnej. Poznań: Księgarnia Świętego Wojciecha, 2002.

OSEWSKA, Elżbieta. "Kierunki współczesnej katechezy rodzinnej odczytane w literaturze pedagogiczno-katechetycznej." In OSEWSKA and STALA, Drogi katechezy rodzinnej, 9-38.

OSEWSKA, Elżbieta. “Komunikacja wiary w rodzinie.” Katecheta 39, no. 3 (1995): 139-43.

PAUl VI. "Przemówienie na audiencji ogólnej (11.08.1976)." Wiadomości Archidiecezjalne Warszawskie 57, nos. 11-12 (1977): 279-81.

Polish Bishops' CONFERENCE. Dyrektorium katechetyczne Kościoła katolickiego w Polsce [Catechetical Directory of the Catholic Church in Poland]. Kraków: WAM, 2001.

Polish Bishops' Conference. Podstawa programowa katechezy Kościoła katolickiego w Polsce [Core Curriculum for Catholic catechesis in Poland]. Częstochowa: Edycja Świętego Pawła, 2018.

PORĘBA, Piotr. “Rodzina chrześcijańska 'małym Kościołem'.” In Wychowanie w rodzinie chrześcijańskiej, edited by Franciszek Adamski, 182-200. Kraków: Wydawnictwo Apostolstwa Modlitwy, 1982.

PORĘBA, Piotr. "Wychowanie religijne w rodzinie.” In Wychowanie w rodzinie chrześcijańskiej, edited by Franciszek Adamski, 185-202. Warsaw: Ośrodek Dokumentacji i Studiów Społecznych, 1973.

SkreczKo, Adam. Troska Kościola katolickiego w Polsce o matżeństwo i rodzinę w okresie Wielkiej Nowenny (1957-1966). Białystok: Wydawnictwo Uniwersytetu w Białymstoku, 2002.

SŁOTwIŃSKA, Helena. "Katechumenat rodzinny jako miejsce formacji do wiary dojrzałej w ujęciu Sługi Bożego ks. Franciszka Blachnickiego.” In Ksiądz Franciszek Blachnicki - katechetyk i pastoralista. W dwudziestą rocznicę śmierci Stugi Bożego, edited by Roman Buchta, 190-202. Katowice: Księgarnia św. Jacka, 2009.

Augustine. Sermo 94. In Patrologia Latina, 38:580-1.

STALA, Józef. $W$ kierunku integralnej edukacji religijnej w rodzinie (Próba refleksji nad nauczaniem Jana Pawła II w kontekście polskich uwarunkowań). Tarnów-Lublin: Polihymnia, 2010. 
VATICAN COUNCIL II. Decree on the Apostolate of the Laity Apostolicam actuositatem, November 18, 1965: AAS 58 (1966), 837-64. http://www.vatican.va/archive/hist_councils/ii_vatican_council/ documents/vat-ii_decree_19651118_apostolicam-actuositatem_en.html.

VATICAN COUNCIL II. Declaration on Christian Education Gravissimum educationis, October 28, 1965: AAS 58 (1966), 728-39. http://www.vatican.va/archive/hist_councils/ii_vatican_council/ documents/vat-ii_decl_19651028_gravissimum-educationis_en.html.

Vatican Council II. Dogmatic Constitution on the Church Lumen Gentium, November 21, 1964: AAS 57 (1965), 5-67. https://w2.vatican.va/archive/hist_councils/ii_vatican_council/documents/ vat-ii_const_19641121_lumen-gentium_en.html.

WILK, Józef. "Rola katechumenatu rodzinnego w inicjacji eucharystycznej dziecka.” Roczniki Teologiczno-Kanoniczne 23, no. 6 (1976): 63-75.

Wstuchani w Ducha. Uchwały II Synodu Archidiecezji Katowickiej. Katowice: Księgarnia św. Jacka, 2016.

Wysocki, Józef. Rytuat rodzinny. Aby rodzina była bardziej Kościołem. Olsztyn: Warmińskie Wydawnictwo Diecezjalne, 1990.

Zarządzenie Arcybiskupa Katowickiego Wiktora Skworca z dnia 4 maja 2020 roku o częściowej zmianie regulacji prawnych [Order of Archbishop of Katowice Wiktor Skworc of 3 May 2020 on partial modification of legal regulations]. Archidiecezja Katowicka, May 4, 2020. https://www.archidiecezja katowicka.pl/o-diecezji/aktualnosci/1277-czesciowa-zmiana-regulacji-prawnych-2.

\section{MISTAGOGICZNY WYMIAR FORMACJI CHRZEŚCIJAŃSKIEJ WE WSPÓLNOCIE RODZINNEJ}

\section{Streszczenie}

Przeżywana w 2020 roku ogólnoświatowa pandemia koronawirusa spowodowała wprowadzenie surowych ograniczeń regulujących wszystkie przestrzenie życia społecznego. Dotyczyły one także możliwości uczestnictwa wiernych w liturgii oraz w codziennym życiu wspólnoty Kościoła. Skutkiem tego, wielu wiernych przeżywało liturgiczne obchody Wielkiejnocy oraz kolejnych niedziel paschalnych we wspólnocie najbliższej rodziny. Zgodnie ze wskazaniami biskupów, także we wspólnocie rodzinnej miało miejsce bezpośrednie przygotowanie dzieci do przyjęcia sakramentu pokuty i pojednania oraz I Komunii św. Rodziny stanęły zatem wobec konieczności wypełnienia zadań właściwych dla katechumenatu. Wobec powyższego, można postawić pytanie, czy w taki właśnie sposób - jako wspólnotę „,domowego Kościoła” - postrzegają siebie współczesne chrześcijańskie rodziny? Czy są świadome swojej misji i odpowiednio do jej podjęcia przegotowane? Celem artykułu jest wydobycie mistagogicznego wymiaru formacji chrześcijańskiej we wspólnocie rodzinnej. Autor podejmuje refleksję nad rodziną jako miejscem urzeczywistnia się misterium Kościoła. Omawia także cele i zadania katechumenatu rodzinnego, podejmowane z racji udziału rodziny w życiu i misji Kościoła.

Słowa kluczowe: mistagogia; formacja chrześcijańska; rodzina; wspólnota; Kościół domowy. 